\title{
ULTRASOUND-ASSISTED EXTRACTION ANTIOKSIDAN SERAT PANGAN DARI TONGKOL JAGUNG (Zea mays L.)
}

\author{
Edi Suryanto $^{1 *}$ dan Mercy R.I. Taroreh ${ }^{2}$ \\ ${ }^{1}$ Program Studi Kimia, Fakultas Matematika dan Ilmu Pengetahuan Alam Universitas Sam Ratulangi, \\ ${ }^{2}$ Program Studi Ilmu dan Teknologi Pangan Fakultas Pertanian, Universitas Sam Ratulangi, \\ Jl. Kampus Unsrat, Kleak, Manado 95115 Sulawesi Utara
}

\begin{abstract}
ABSTRAK
Tujuan penelitian ini adalah menentukan pengaruh pelarut dan waktu ekstraksi berbantu ultrasonik dari tepung serat pangan tak larut (SPTL) dari tongkol jagung dan aktivitas antioksidannya. Etanol dan aseton digunakan untuk mengektrak komponen fenolik dri tepung IDF tongkol jagung dengan waktu ekstraksi (30, 60, 90, 120, 150 dan 180 menit) pada dievaluasi berdasarkan kandungan fenolik dan aktivitas antioksidan dari ekstrak tanaman. Hasil penelitian menunjukkan bahwa ekstrak etanol memiliki kandungan fenolik tertinggi dibandingkan dengan aseton ekstrak semua tingkat waktu ekstraksi. Hasil ini juga menunjukkan bahwa ekstrak etanol memiliki aktivitas antioksidan yang lebih kuat dalam aktivitas pemulungan radikal dan mengurangi daya antioksidan. Studi ini menyimpulkan bahwa waktu ekstraksi dan jenis pelarut mempengaruhi total kandungan fenolik dan aktivitas antioksidan.
\end{abstract}

Kata kunci: Tongkol jagung, serat pangan, ultrasonik, waktu ekstraksi, fenolik, antioksidan

\begin{abstract}
The objective of this study was to determine solvents effect and extraction time of ultrasound-assisted extraction of corncob insoluble dietary fiber (IDF) powder and their antioxidant activities. Ethanol and acetone were used to extract phenolic components from corncob IDF powder with extraction time (30, 60, 90, 120, 150 and $180 \mathrm{~min})$ in an ultrasonic bath (Krisbow $42 \mathrm{kHz}, 50$ watt). The both extracts were evaluated on the phenolic content and antioxidant activity with spectrophotometry method. The results of the phenolics content expressed in $\mu \mathrm{g} / \mathrm{mL}$ of gallic acid equivalent showed that ethanol extract has highest phenolic content compared with acetone extract of all the extraction time. The radical scavenging activity of extract ethanol exhibited strong than acetone extract of all extraction time tested. The result also showed that the ethanol extract has highest the total antioxidant capacity compared with acetone extract at all extraction time. This result suggest that corncob IDF powder especially the ethanol extract are very rich in phenolic component which is potential as antioxidant dietary fiber.
\end{abstract}

Keyword: corncob, dietary fiber, ultrasonic, extraction time, phenolic, antioxidant

\section{PENDAHULUAN}

Indonesia merupakan salah satu negara pertanian penghasil jagung dalam bentuk pipilan kering. Berdasarkan data dari Badan Pusat Statistik (BPS, 2017), produksi jagung Nasional sebesar 28,90 juta ton pipilan kering. Produksi jagung pipilan yang melimpah ini menghasilkan 8,67 juta ton tongkol jagung. Tongkol jagung mengandung komponen selulosa (41\%), hemiselulosa (36\%), lignin (6\%) dan pektin (3\%) sehingga memungkinkan untuk dimanfaatkan sebagai sumber serat pangan dan fitokimia antioksidan (Retnoningtyas dkk., 2013; Suryanto dkk., 2013).

Serat pangan telah terbukti memiliki peran penting dalam pencegahan resiko karsinogenesis, aterosklerosis, serta mengendalikan pelepasan glukosa dengan waktu tertentu sehingga membantu dalam pengelolaan diabetes mellitus dan obesitas yang tepat (Trinidad dkk., 2001). Beberapa studi melaporkan bahwa tongkol jagung mengandung senyawa fenolik, flavonoid, tannin dan memiliki aktivitas antioksidan, singlet oxygen quenching dan tabir surya (Suryanto dkk., 2013; Suryanto \& Momuat, 2017). Senyawa fenolik dapat mencegah resiko kanker, penyakit jantung koroner, stroke, artherosclerosis, ospteoporosis, inflamasi dan penyakit neurodegeneratif yang berhubungan dengan stress oksidatif (Ames \& Shigenaga, 1993; Shahidi \& Naczk, 1995; Halliwel \& Gutterige, 2001). Dalam beberapa tahun terakhir, ekstraksi Ultrasound-assisted extraction (UEA) sebagai

\footnotetext{
* Korespondensi:

Telepon: +62 853-9856-6170

Email: edi7suryanto@gmail.com

DOI: https://doi.org/10.35799/cp.12.2.2019.27315
} 
teknik baru untuk ekstraksi jaringan tanaman mendapat perhatian yang meningkat (Shotipruk dkk., 2001; Djilani dkk., 2006; Ou dkk., 1997).

UEA telah telah terbukti dapat meningkatkan efisiensi ekstraksi dan waktu ekstraksi. Selain itu, UEA juga dapat dilakukan pada suhu yang lebih rendah untuk menghindari terjadinya kerusakan akibat pemanasan. Mason dkk. (1996) menyatakan bahwa peningkatan ekstraksi pelarut dari bahan oleh UEA terutama disebabkan efek mekanis dari kavitasi akustik, yang dapat meningkatkan perpindahan massa dan penetrasi pelarut ke dalam bahan tanaman dengan menghancurkan sel-sel dalam tanaman. Oleh karena itu, untuk mencapai yang efisiensi tinggi dalam ekstraksi dinding sel tanaman, optimalisasi dari parameter operasional ultrasonik seperti pelarut, polaritas, waktu, $\mathrm{pH}$ merupakan faktor yang paling penting. Ekstraksi sonikasi dapat dilakukan untuk mengekstraksi antioksidan dalam suatu bahan (Peres dkk., 2006). Tujuan penelitian ini adalah menentukan pengaruh pelarut and waktu ekstraksi berbantu ultrasonic (Ultrasound-assisted extraction) dari tepung serat pangan tak larut (SPTL) dari tongkol jagung dan aktivitas antioksidannya.

\section{BAHAN DAN METODE}

\section{Alat dan bahan}

Bahan yang digunakan dalam penelitian yaitu tongkol jagung Manado kuning yang diperoleh dari Ratahan, Kecamatan Minahasa Tenggara Sulawesi Utara. Bahan yang digunakan adalah etanol, natrium karbonat, reagen FolinCiocelteu $50 \%$, larutan buffer fosfat $(0,2 \mathrm{M} \mathrm{pH}$ 7), kalium ferisianat, asam trikloroasetat, Besi(III) klorida danaquades. Alaf yang digunakan yaitu alat-alat gelas, vortex, kertas saring, aluminium foil, timbangan analitik, rotary evaporator, blender, milling (Fomac tipe FCTZ200 tegangan $220 \mathrm{~V}$ daya $1 \mathrm{KW}$ frekuensi 50$60 \mathrm{~Hz}$ kecepatan putar $28.000 \mathrm{rpm}$ ), ayakan, 150 dan $75 \mu \mathrm{m}$, rak tabung, micro pipet, gelas ukur, oven, petridis, desikator, sudip, botol vial, sentrifugasi, spektrofotometer UV-Vis (Shimadzu) dan sonikator (Krisbow $40 \mathrm{KHz}$ ).

\section{Preparasi sampel}

Sampel tongkol jagung yang telah dipotong-potong dibersihkan dan dicuci dengan air untuk memisahkan bagian yang terapung. Setelah itu $1000 \mathrm{~g}$ tongkol jagung diblender dengan aquades selama 2 menit dan disaring menggunakan kain blacu, Ampas tongkol jagung kemudian dipanaskan dengan aquades $1000 \mathrm{~mL}$ selama 1 jam sambil diaduk. Kemudian disaring untuk memisahkan ampas dengan filtrat, ampas selanjutnya dikeringkan di dalam oven pada suhu $50-60{ }^{\circ} \mathrm{C}$ selama 48 jam (kadar airnya < 10\%). Tongkol jagung yang sudah kering digiling menggunakan alat miling Fomac tipe FCT-Z200 selama 2 menit. Hasil miling dalam bentuk tepung, kemudian di ayak menggunakan ayakan 200 mesh (tepung serat pangan tak larut) dan disimpan dalam kantong plastik sebelum digunakan untuk ekstraksi dan analisis.

\section{Ektraksi tongkol jagung}

Tepung serat pangan tak larut dari tongkol jagung (200 mesh) ditimbang sebanyak $5 \mathrm{~g}$ diekstraksi secara sekuensial dengan $50 \mathrm{~mL}$ etanol $80 \%$ dan aseton $80 \%$ kemudian disonikasi dengan frekuensi $40 \mathrm{kHz}$ selama 30, 60, 90, 120, 150 dan 180 menit, setelah disonikasi sampel disaring, dan dipekatkan menggunakan rotari evaporator, Ekstrak yang diperoleh disimpan pada suhu $0{ }^{\circ} \mathrm{C}$ sebelum dianalisis kandungan total fenolik dan aktivitas antioksidannya.

\section{Penentuan kandungan total fenolik}

Kandungan total fenolik ditentukan menggunakan metode Jeong dkk. (2004). Sebanyak $0,1 \quad \mathrm{~mL}$ sampel $1000 \quad \mu \mathrm{g} / \mathrm{mL}$ dimasukkan ke dalam tabung reaksi, lalu ditambahkan 0,1 mL reagen Folin Ciocalteu $50 \%$ dalam tabung reaksi dan kemudian campuran divortex selama 3 menit. Setelah interval waktu 3 menit, ditambahkan $2 \mathrm{~mL}$ larutan $\mathrm{Na}_{2} \mathrm{CO}_{3} 2 \%$, kemudian campuran diinkubasi dalam ruang gelap selama 30 menit. Selanjutnya dibaca dibaca absorbansinya pada $\lambda 750 \mathrm{~nm}$ dengan menggunakan spektrofotometer UV-Vis.

\section{Penentuan penangkal radikal bebas DPPH}

Penentuan aktivitas aktioksidan menggunakan metode penangkal radikal bebas DPPH Gaulejac dkk. (1998). Dipersiapkan sebanyak 2 mL larutan 1,1-difenil-2-pikrilhidrazil (DPPH) $93 \mu \mathrm{M}$ dalam etanol dan ditambahkan $0,5 \mathrm{~mL}$ ekstrak etanol dan ekstrak aseton. Berubahnya warna larutan dari ungu ke warna kuning menunjukkan efisiensi penangkap radikal. Selanjutnya diinkubasi selama 30 menit dan absorbansi diukur pada $\lambda 517 \mathrm{~nm}$ dengan spektrofotometer UV-Vis. Aktivitas penangkalan radikal bebas (APRB) dihitung sebagai persentase berkurangnya warna DPPH dengan menggunakan persamaan berikut ini: 
$\operatorname{APRB}(\%)=\left[1-\frac{\text { absorbansi sampel }}{\text { absorbansi kontrol }}\right] \times 100 \%$

\section{Penentuan total antioksidan}

Penentuan total antioksidan ditentukan menurut metode ferric reducing ability of plasma (FRAP) (Benzie \& Strain, 1996; Halvorsen dkk., 2001). Pengukuran dilakukan dengan mengambil $0,1 \mathrm{~mL}$ ekstrak yang dilarutkan dalam etanol dicampurkan dengan $3 \mathrm{~mL}$ reagen FRAP dalam keadaan segar. Kemudian campuran dikocok dengan alat vortex dan setelah itu, segera dilakukan pengukuran absorbansinya pada panjang gelombang $593 \mathrm{~nm}$. Reagen FRAP selalu dipersiapkan dalam keadaan segar dengan mencampurkan 2,5 mL, $10 \mathrm{mM}$ larutan 2,4,6tripiridil-s-triazina (TPTZ) dalam $40 \mathrm{mM} \mathrm{HCl}$ $\mathrm{mM}$ dengan 2,5 mL, $20 \mathrm{mM}$ larutan $\mathrm{FeCl}_{3} 6 \mathrm{H}_{2} \mathrm{O}$ dan 2,5 mL, 0,3 M buffer asetat pada $\mathrm{pH} 3,6$. Kandungan total antioksidan dinyatakan sebagai ekuivalen $\mathrm{Fe}^{3+}$ menjadi $\mathrm{Fe}^{2+}$ dalam $\mu \mathrm{mol} / \mathrm{L}$ ekstrak. Untuk membuat kurva standar dipersiapkan pada cara yang sama menggunakan larutan $\mathrm{FeSO}_{4}$ dengan konsentrasi antara 100$1000 \mu \mathrm{mol} / \mathrm{L}$.

\section{Analisis statistik}

Semua data eksperimen dilakukan dua kali ulangan dan hasilnya dinyatakan sebagai rataan \pm SD. Apabila perlakuan berpengaruh nyata, pengujian beda rataan perlakuan dilanjutkan dengan uji beda rataan dengan DMRT (Duncan's multiple range test). Analisis dilakukan menggunakan software SPSS versi 18.

\section{HASIL DAN PEMBAHASAN}

\section{Kandungan total fenolik}

Senyawa fenolik merupakan salah satu kelompok senyawa fitokimia yang memiliki satu atau lebih cincin aromatik dengan satu atau lebih gugus hidroksil. Senyawa ini tersebar luas dalam tumbuhan dan merupakan metabolit sekunder yang melimpah dalam tumbuhan (Dai \& Mumper, 2010). Kelarutan senyawa fenolik bergantung pada pelarut yang digunakan. Komponen polifenol memiliki spektrum yang luas dengan sifat kelarutan yang berbeda-beda. Hal inilah yang menyebabkan sulitnya prosedur ekstraksi yang cocok untuk mengekstrak fenolik pada tanaman (Naczk \& Shahidi, 2004).

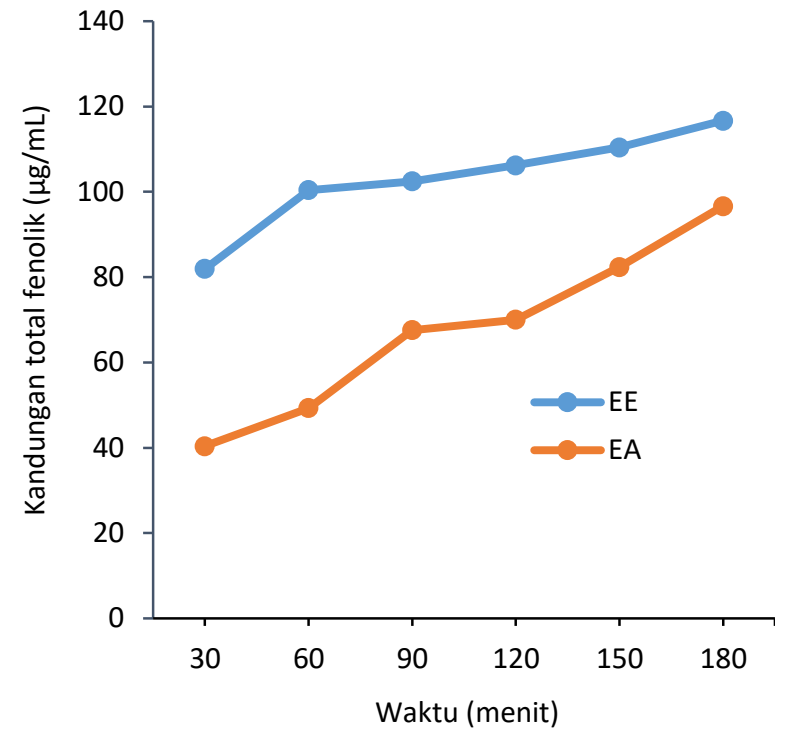

Gambar 1. Kandungan total fenolik ekstrak etanol (EE) and ekstrak aseton (EA) dengan perlakuan waktu ekstraksi

Penentuan kandungan total fenolik dilakukan menggunakan metode Folin-Ciocalteu. Prinsip ini dedasarkan pada kemampauan sampel untuk mereduksi reagen Folin-Ciocalteu yang mengandung senyawa fosfomolibdatfosfotungstat. Pada saat reagen Folin-Ciocalteu dan senyawa fenolik direaksikan akan terjadi perubahan warna dari kuning menjadi biru sehingga dapat ditentukan secara spektrofotometer (Suryanto, 2012). Berdasarkan Gambar 1 dapat diketahui bahwa kandungan fenolik tertinggi terdapat pada EE dan yang terendah pada EA. Hal ini menunjukan bahwa kandungan fenolik lebih banyak terektraksi dengan pelarut etanol dibandingan dengan pelarut aseton pada saat proses ekstraksi sonikasi. Pelarut yang digunakan dalam proses ekstraksi adalah pelarut polar yaitu etanol, selain bersifat polar etanol juga memiliki gugus $\mathrm{C}_{2} \mathrm{H}_{5}$ yang relatif berperan sebagai senyawa non polar. Dengan demikian adanya sifat dan gugus tersebut membuat etanol hampir dapat melarutkan semua produk metabolit sekunder. Perubahan warna biru yang teramati berbanding lurus dengan konsentrasi ion fenolat yang terbentuk, dimana semakin besar konsentrasi senyawa fenolik maka semakin besar ion fenolat yang terbentuk sehingga warna biru yang dihasilkan semakin pekat.

\section{Spektra UV}

Othman dkk. (2014) menyatakan bahwa ekstraksi komponen fenolik sampel bergantung pada kecocokkan komponen dengan sistem 
pelarut berdasarkan prinsip like dissolves like. Setiap pelarut memiliki efektivitas yang berbeda dalam melarutkan senyawa fenolik, tergantung pada kesesuaian polaritas dari pelarut dan senyawa fenolik. Baik senyawa fenolik maupun flavonoid merupakan substansi yang mempunyai cincin aromatik dengan satu atau lebih gugus hidroksil, sehingga sifatnya mudah larut dalam pelarut polar. Pelarut yang bersifat polar mampu melarutkan fenol lebih baik sehingga kadar total fenol dan flavonoid pada ekstrak menjadi tinggi. Metode ekstraksi yang digunakan adalah ekstraksi sonikasi yang memanfaatkan energi gelombang suara untuk mengganggu partikel dalam sampel. Getaran yang dihasilkan mempercepat waktu kontak antara sampel dengan pelarut sehingga proses pemisahan senyawa dari sampel ke pelarut menjadi lebih cepat.

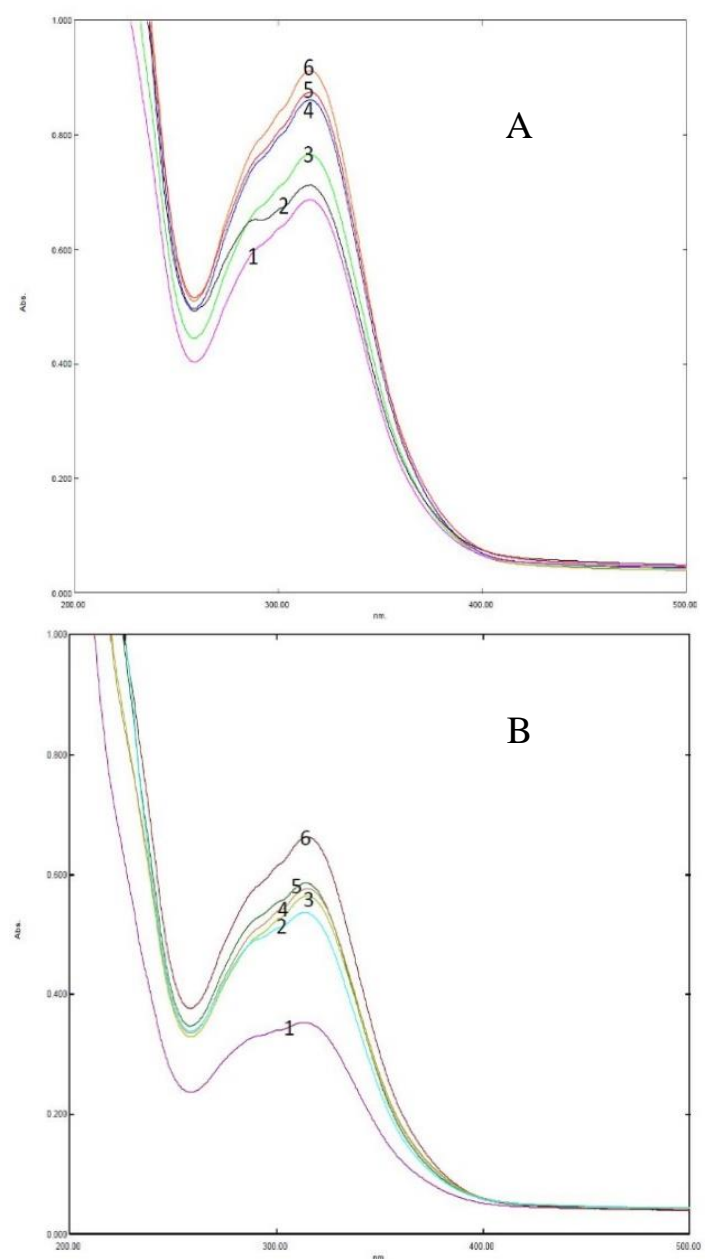

Gambar 2.Spektrum UV ekstrak etanol (A) dan ekstrak aseton (B) dengan perlakuan waktu ekstraksi (1. 30, 2. 60, 3. 90, 4. 120, 6. 150 dan 180 menit)

Gambar 1 (A, B) menunjukkan spektra UV senyawa fenolik yang diekstraksi dari tepung tongkol jagung dengan pelarut etanol dan aseton.
Hasil spectrum UV pada $\lambda$ 200-400 nm menunjukan adanya senyawa fenolik pada ekstrak etanol (EE) maupun ekstrak aseton (EA) dalam semua level waktu ekstraksi.Pada waktu 180 menit menunjukan absorbansi paling tinggi yang diikuti dengan waktu 150, 120, 90, 60 dan 30 menit untuk kedua pelarut tersebut. Spektra UV memperlihatkan bahwa EE memiliki spektra dengan absorbansi yang lebih tinggi dibandingkan dengan hasil spektra EA. Hal ini berbanding lurus dengan hasil uji kandungan total fenolik dimana pelarut etanol memiliki kandungan total fenolik yang tinggi dibandingkan dengan pelarut aseton. Lebih tingginya absorbansi pada hasil spektra dengan pelarut etanol menunjukkan bahwa pelarut etanol pada tongkol jagung mampu mengekstrak senyawa fenolik lebih baik.

\section{Aktivitas penangkal radikal bebas DPPH}

Pengujian aktivitas antioksidan dengan radikal 1,1-difenil-2-picrylhidrazy (DPPH) digunakan untuk menentukan aktivitas penangkal radikal bebas dari ekstrak tanaman maupun senyawa murni. Prinsip dari metode ini merupakan kemampuan dari ekstrak tersebut dapat menangkal radikal bebas melalui pemberian hidrogen kepada radikal bebas DPPH yang berwarna ungu akan berubah menjadi non radikal yang berwarna kuning. Semakin berkurangnya warna ungu menunjukkan bahwa kemampuan antioksidan tersebut untuk menangkal radikal bebas DPPH semakin kuat (Molyneux, 2004). Pengukuran aktivitas antioksidan sampel dilakukan pada panjang gelombang $517 \mathrm{~nm}$ yang merupakan panjang gelombang maksimum DPPH. Pengujian aktivitas penangkal radikal bebas dari ekstrak etanol (EE) dan ekstraks aseton(EA) dengan perlakuaan waktu ekstraksi sonikasi dapat dilihat pada Gambar 3.

Aktivitas antioksidan dari ekstrak tongkol jagung dinyatakan dalam persentase penangkal terhadap radikal DPPH. Persentase penangkalan didapatkan dari perbedaan serapan antara absorban DPPH dengan absorban sampel yang diukur dengan spektrofotometer UV-Vis. Semua sampel menunjukkan aktivitas penangkal radikal bebas DPPH di atas 50\% pada semua waktu ekstraksi sonikasi.Aktivitas antioksdian terbesar ditunjukkan oleh EE dibandingan dengan EA.Hal ini dibuktikan dengan terjadinya perubahan warna ungu menjadi kuning, saat ekstrak ditambahkan larutan DPPH. Larutan DPPH yang awalnya berwarna ungu setelah bereaksi dengan 
kedua ekstrak akan membentuk warna kuning. Semakin tinggi kandungan antioksidan maka warna ungu pada larutan DPPH akan semakin berkurang pembentukan warna kuning. Perubahan warna ini akan mengakibatkan penurunan nilai absorbansi sinar tanpak dari spektrofotometer (Molyneux, 2004.)

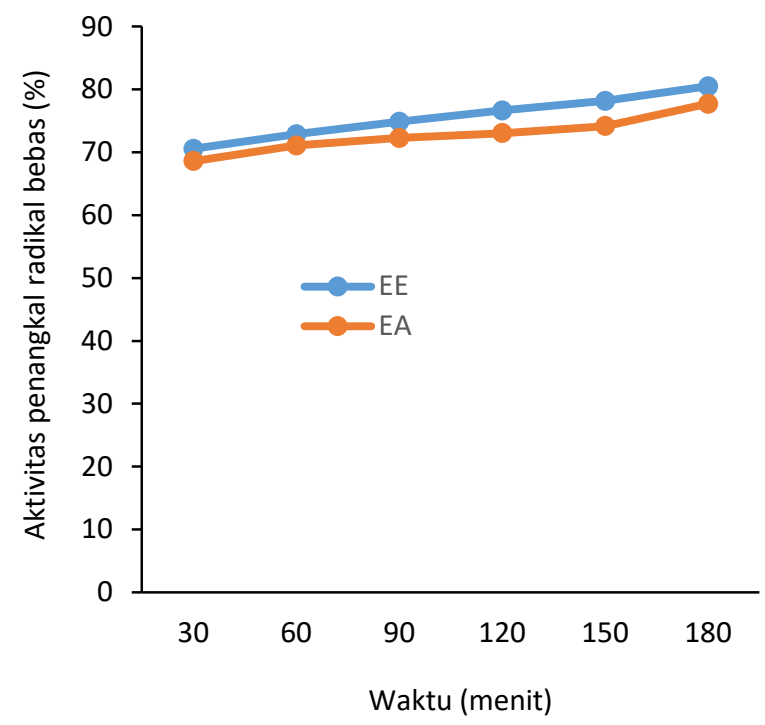

Gambar 3 Aktivitas penangkal radikal bebas ekstrak etanol (EE) and ekstrak aseton (EA) dengan perlakuan waktu ekstraksi sonikasi.

Aktivitas penangkal radikal bebas EE menunjukkan paling tinggi daripada EA pada semua waktu ekstraksi sonikasi. Hal ini berarti bahwa ekstrak tongkol jagung dengan pelarut etanol mengandung senyawa-senyawa bioaktif yang dapat berfungsi sebagai antioksidan yang lebih baik dibandingkan dengan ekstrak tongkol jagung dengan pelarut aseton sehingga lebih efektif dalam menangkal radikal bebas DPPH. Hasil penelitian ini juga menunjukkan bahwa aktivitas penangkal radikal bebas DPPH kedua ekstrak sejalan dengan sejumlah kandungan total fenolik pada semua waktu ekstraksi dengan sonikasi. Beberapa penelitian melaporkan bahwa ada hubungan yang kuat antara kandungan total fenolik dengan aktivitas penangkal radikal bebas DPPH dari ekstrak tanaman (Tomsone dkk., 2012; Alothman dkk., 2009; Yao, dkk., 2010; Agbor dkk., 2005; Li dkk., 2009).

\section{Total antioksidan}

Metode FRAP (ferric reducing antioxidant power) merupakan salah satu metoda penentuan kapasitas total antioksidan secara spektrofotometri yang berdasarkan pada reduksi analog ferroin, kompleks $\mathrm{Fe}^{3+}$ dari tripiridiltriazin $\mathrm{Fe}(\mathrm{TPTZ})^{3+}$ menjadi kompleks $\mathrm{Fe}^{2+}, \mathrm{Fe}(\mathrm{TPTZ})^{2+}$ yang berwarna biru oleh senyawa antioksidan pada suasana asam. Hasil pengujian diinterpretasikan dengan peningkatan absorbansi pada panjang gelombang $593 \mathrm{~nm}$ dan dapat disimpulkan sebagai jumlah $\mathrm{Fe}^{2+}$ (dalam mikromolekular) ekuivalen dengan antioksidan standar. Penentuan nilai kapasitas total antioksidan dalam sampel dilakukan dengan mencampurkan reagen FRAP dengan ekstrak sampel. Dalam reagen FRAP terdapat campuran TPTZ, $\mathrm{FeCl}_{3}$ dan buffer asetat, sehingga reagen FRAP merupakan senyawa komplek $\mathrm{Fe}^{3+}$-TPTZ yang tidak berwarna menjadi komplek $\mathrm{Fe}^{2+}$ yang berwarna biru. Semakin banyak konsentrasi $\mathrm{Fe}^{3+}$ TPTZ yang direduksi oleh sampel menjadi $\mathrm{Fe}^{2+}$ TPTZ, maka kapasitas total antioksidan dari sampel juga semakin besar (Pisoschi \& Negulescu, 2011). Kandungan kapasitas total antioksidan pada ekstrak etanol (EE) dan esktrak aseton (EA) dari tepung tongkol jagung dapat dilihat pada Gambar 4.

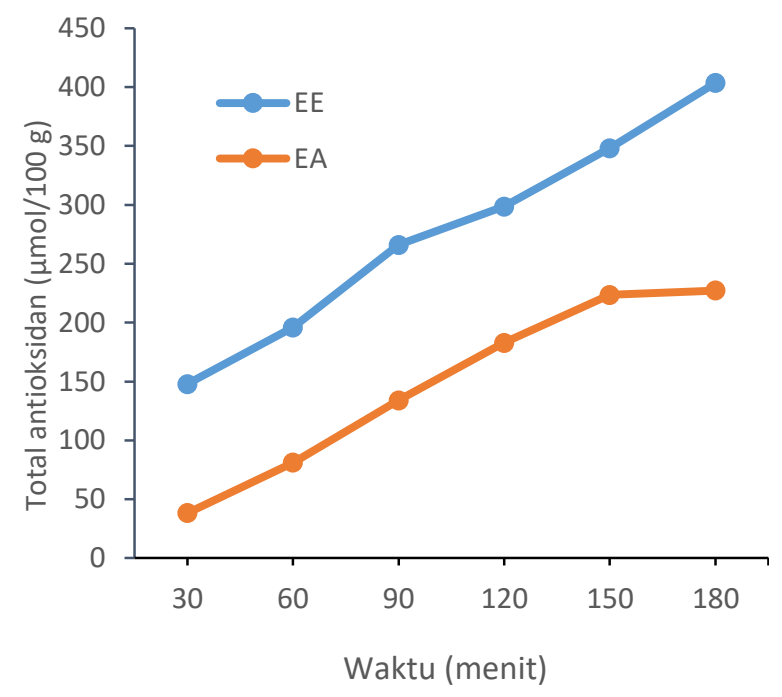

Gambar 4. Total antioksidan ekstrak etanol (EE) and ekstrak aseton (EA) dengan perlakuan waktu ekstraksi sonikasi.

Hasil penelitian ini menunjukkan bahwa EE memiliki kapasitas total antioksidan lebih tinggi daripada ekstrak aseton (EA) pad semua level waktu ekstraksi dengan sonikasi $(\mathrm{p}<0,05)$. Total antioksidan yang rendah pada EA berkaitan dengan rendahnya kontribusi senyawa fenolik sebaliknya kandungan total fenolik tinggi menunjukkan hubungan dengan kapasitas total antioksidan. Menurut Althoman dkk. (2009), kandungan total fenolik tinggi menunjukkan tinggi pula kapasitas total antioksidan dan aktivitas penangkal radikal bebas dari ekstrak nenas, pisang dan jambu. 
Kapasitas total antioksidan yang tinggi pada EE menunjukkan lebih banyaknya kandungan senyawa fenolik yang dapat mereduksi ion $\mathrm{Fe}^{3+}$ menjadi $\mathrm{Fe}^{2+}$ daripada EA. Oleh karena itu, kehadiran senyawa fenolik dalam ektrak etanol dapat meningkatan aktivitas antioksidan dan mampu berperan sebagai donor elektron yang selanjutnya menghakhiri reaksi rantai radikal dengan mengubah radikal bebas menjadi produk yang lebih stabil.

\section{KESIMPULAN}

Hasil penelitian menunjukkan bahwa pelarut terbaik untuk menghasilkan ekstrak fenolik dari tepung serat pangan tongkol jagung adalah etanol $80 \%$ pada semua level waktu ekstraksi sonikasi. Hasil penelitian juga menunjukkan bahwa ekstrak etanol memiliki aktivitas penangkal radikal bebas dan total antioksidan paling tinggi dibandingkan dengan ekstrak aseton pada semua level waktu ekstraksi sonikasi. Ada kecendrungan bahwa peningkatan waktu ekstraksi berbantukan ultrasonik memiliki kandungan fenolik dan aktivitas antioksidan yang tinggi.

\section{UCAPAN TERIMA KASIH}

Penulis mengucapkan terima kasih kepada Pimpinan Peningkatan Penelitian Perguruan Tinggi: Riset Dasar Unggulan Perguruan Tinggi (RDUPT) Tahun 2019. Direktorat Penelitian dan Pengabdian Kepada Masyarakat, Direktorat Jenderal Pendidikan Tinggi, Kementerian Pendidikan Riset, Teknologi dan Pendidikan Tinggi.

\section{DAFTAR PUSTAKA}

Agbor, G.A., Oben, J.E., Ngogang, J.Y., Xinxing, C. \& Vinson, J.A. 2005. Antioxidant capacity of some herbs/spices from cameroon: A comparative study of two methods. Journal of Agricultural and Food Chemistry. 53(17): 6819-6824.

Alothman, M., Bhat, R. \& Karim, A.A. 2009. Antioxidant capacity and phenolic content of selected tropical fruits from Malaysia, extracted with different solvents. Food Chemistry. 115(3): 785-788.

Ames, B.N. \& Shigenaga. M.K. 1993. Oxidants are a major contributor in cancer and aging. Dalam B. Haliwell and O.I. Aruoma
(Eds). DNA and Free Radicals, Ellis Horwoosd Ltd., West Sussex, U.K.

Antari, N.M.R.O., Wartini, N.M. \& Mulyani, S. 2015. Pengaruh ukuran partikel dan lama ekstraksi terhadap karakteristik ekstrak warna alami buah pandan (Pandanus tectorius). Jurnal Rekayasa dan Manajemen Agroindustri. 3(4), 30-40.

Badan Pusat Statistik (BPS). 2017. http://www.bps.go.id

Benzie, I.F.F. \& Strain, J.J. 1996. The ferric reducing ability of plasma (FRAP) as a measure of "Antioxidant Power": The FRAP assay. Analytical Biochemistry. 1(15), 70-76.

Dai, J. \& Mumper, R.J. 2010. Plant Phenolic: Extraction Analysis and Their Antioxidant and Anticancer Properties. Molecules. 15(10), 7313-7352.

Djilani, A., Legseir, B. Soulimani, R., Dickob, A. \& Younos, Y. 2006. New extraction technique for alkaloids. Jounal Brazilia and Chemical Society. 17(3), 518-520.

Gaulejac, N.S-C., Provost, C. \& Vivas, N. 1998. Comparative study of polyphenol scavenging activities assessed by different methods. Journal of Agriculture and Food Chemistry. 47(2), 425-431.

Halliwel, B. \& Gutteridge. J.M.C. 2001. Free radicals in biology and medicine. London: Oxford University Press.

Jeong, S.M., Kim, S.Y., Kim, D.R., Jo, S.C., Nam, D.U. \& Lee, S.C. 2004. Effect of heat treatment on the antioxidant activity of extracts from citrus peels. Journal of Agriculture and Food Chemistry. 52(11), 3389-3393.

Li, X., Wu, X. \& Huang, L. (2009). Corelation between antioxidant activities and phenolic contents of Radix angelicae sinensis (Danggul). Molecules. 14(12), 5349-5361.

Mason, T.J., Paniwnyk, L. \& Lorimer, J.P. 1996. The uses of ultrasound in food technology. Ultrasonic Sonochemical. 3(3), S253-S260.

Molyneux, P. 2004. The use of the stable free radikal diphenyl picrylhydrazyl (DPPH) for estimating antioxidant activity. Journal Science of Technology. 26(2), 211-219.

Naczk, M. \& Shahidi, F. 2004. Extraction and analysis of phenolics in food. Journal of Chromatography. 1054 (1-2), 95-111.

Othman, A., Mukthar, N.J., Ismail, N.S. \& Chang, S.K. 2014. Phenolics, flavonoids content and antioxidant activities of 
malaysian herbal plants. International Food Research Journal. 1(2), 759-766.

Ou, L.Z.Q., Jia, Q., Jin,,H.Y., \& Yediler, T.A. \& Ketrrup, S.A. 1997. Ultrasonic extraction and determination of linear alkylbenzene sulfonate in plant tissues. Chromatography A. 4(7-8), 417-420.

Peres, V.L., Saffia, J., Melecchi, M.I.S., Abadc, F.C., Jacques, R.A., Martinez, M.M., Oliveira, E.C. \& Caramao, E.B. 2006. Comparison of soxhlet, ultrasound-assisted and pressurized liquid extraction of terpenes, fatty acids and vitamin e from piper Gaudichaudianum kunth. Journal of Chromatography. 1105(1-2), 115-118.

Pisoschi1, M. \& Negulescu, G.P. 2011. Methods for total antioxidant activity determination: A review. Biochemistry and Anal Biochemistry. 1(1), 1-10.

Retnoningtyas, E.S., Antaresti \& Aylianawati. 2013. Aplikasi crude enzim selulase dari tongkol jagung (Zea mays L.) pada produksi etanol dengan metode simultaneous saccharification and fermentation (SSF). Reaktor. 14(4), 272276.

Shahidi, F. \& Naczk, M. 1995. Food phenolics: sources, chemistry, effects and applications. Lancaster: Technomic Publication Company, Inc.

Shotipruk, A., Kaufman, P.B. \& Wang, H.Y. 2001. Feasibility study of repeated harvesting of menthol biological viable Menth piperata using ultrasonic extraction. Biotechnology Progress. 17(5), 924-928.
Sopyan, I., Wathoni, N., Rusdiana, T. \& Gozali, D. 2018. Karakterisasi sediaan padat farmasi. Yogyakarta: Deepublish.

Suryanto, E. \& Momuat, L.I. 2017. Isolasi dan aktivitas antioksidan fraksi dari ekstrak tongkol jagung (Zea mays). AGRITECH, 37(2). 149-157.

Suryanto, E. 2012. Fitokimia antioksidan. Surabaya: Putra Media Nusantara.

Suryanto, E.L.I. Momuat, A. Yudistira \& Wehantouw, F. 2013. The evaluation of singlet oxygen quenching and sunscreen activity of corncob. Indonesian Journal of Pharmacy. 24(2), 274-283.

Tomsone, L., Kruma, Z. \& Galoburda, R. 2012. Comparison of different solvents and extraction methods for isolation of phenolic compounds from horseradish roots (Armoracia rusticana). International Journal of Biological, Biomolecular, Agricultural, Food and Biotechnological Engineering. 6(4): 237-241.

Trinidad, T.P., Valdez, D., Mallillin, A.C., Askali, F.C., Maglaya, A.S., Chua, M.T., Castillo, J.C., Loyola, A.S. \& Masa, D.B. 2001. Coconut flour from residue: A good source of dietary fiber. Indian Coconut Journal. 7(2006), 45-50.

Yao, Y., Sang, W., Zhou, M. \& Ren, G. (2010). Phenilic composition and antioxidant activities of 11 celery cultivars. Journal of Food Science. 75(1), C9-C13.

Yen, G.C. \& Chen, H.Y. 1995. Antioxidants activity of various tea extracts in relation to their antimutagenicity. Journal of Agriculture and Food Chemistry. 43(1), 2732. 